\title{
Landscape control of uranium and thorium in boreal streams - spatiotemporal variability and the role of wetlands
}

\author{
F. Lidman ${ }^{1}$, C. M. Mörth ${ }^{2}$, and H. Laudon ${ }^{3}$ \\ ${ }^{1}$ Dept. of Ecology and Environmental Sciences, Umeå University, Umeå, Sweden \\ ${ }^{2}$ Dept. of Geology and Geochemistry, Stockholm University, Stockholm, Sweden \\ ${ }^{3}$ Dept. of Forest Ecology and Management, Swedish University of Agricultural Sciences, Umeå, Sweden \\ Correspondence to: F. Lidman (fredrik.lidman@emg.umu.se)
}

Received: 30 January 2012 - Published in Biogeosciences Discuss.: 13 March 2012

Revised: 14 October 2012 - Accepted: 25 October 2012 - Published: 23 November 2012

\begin{abstract}
The concentrations of uranium and thorium in ten partly nested streams in the boreal forest region were monitored over a two-year period. The investigated catchments ranged from small headwaters $\left(0.1 \mathrm{~km}^{2}\right)$ up to a fourthorder stream $\left(67 \mathrm{~km}^{2}\right)$. Considerable spatiotemporal variations were observed, with little or no correlation between streams. The fluxes of both uranium and thorium varied substantially between the subcatchments, ranging from 1.7 to $30 \mathrm{~g} \mathrm{~km}^{-2} \mathrm{a}^{-1}$ for uranium and from 3.2 to $24 \mathrm{~g} \mathrm{~km}^{-2} \mathrm{a}^{-1}$ for thorium. Airborne gamma spectrometry was used to measure the concentrations of uranium and thorium in surface soils throughout the catchment, suggesting that the concentrations of uranium and thorium in mineral soils are similar throughout the catchment. The fluxes of uranium and thorium were compared to a wide range of parameters characterising the investigated catchments and the chemistry of the stream water, e.g. soil concentrations of these elements, $\mathrm{pH}$, TOC (total organic carbon), $\mathrm{Al}, \mathrm{Si}$ and hydrogen carbonate, but it was concluded that the spatial variabilities in the fluxes of both uranium and thorium mainly were controlled by wetlands. The results indicate that there is a predictable and systematic accumulation of both uranium and thorium in boreal wetlands that is large enough to control the transport of these elements. On the landscape scale approximately 65 $80 \%$ of uranium and $55-65 \%$ of thorium entering a wetland were estimated to be retained in the peat. Overall, accumulation in mires and other types of wetlands was estimated to decrease the fluxes of uranium and thorium from the boreal forest landscape by $30-40 \%$, indicating that wetlands play an important role for the biogeochemical cycling of uranium and thorium in the boreal forest landscape. The atmospheric
\end{abstract}

deposition of uranium and thorium was also quantified, and its contribution to boreal streams was found to be low compared to weathering.

\section{Introduction}

Uranium and thorium are the heaviest elements that occur naturally in appreciable levels on Earth. All isotopes of both uranium and thorium are radioactive, but since the half-lives of the most abundant isotopes, ${ }^{238} \mathrm{U},{ }^{235} \mathrm{U}$ and ${ }^{232} \mathrm{Th}$, are long (4.46, 0.704 and 14.0 billion years respectively), they remain ubiquitous in the environment. The average concentration of uranium in continental crust has been estimated to be $2.5 \mathrm{\mu g} \mathrm{g}^{-1}$ (Wedepohl, 1995), which means that uranium is as abundant as arsenic and tin. According to the same estimations, thorium is about four times more common with an estimated average concentration of $10 \mu \mathrm{g} \mathrm{g}^{-1}$. Hence, thorium is nearly as abundant as copper, cobalt and lead. Uranium and thorium are also the only representatives of the actinide series to occur in significant quantities in the environment, making them interesting as natural analogues, for example, for some of the transuranium elements.

Whereas thorium is only present as Th(IV) in natural waters, uranium occurs in multiple redox states, U(IV) and $\mathrm{U}(\mathrm{VI})$ being most common. Th(IV) and U(IV) are generally considered to have low solubility, while $\mathrm{U}(\mathrm{VI})$ often is more mobile (Langmuir and Herman, 1980; Andersson et al., 1995). Areas of naturally high concentrations of uranium and thorium are found throughout the world, causing both radiological and toxicological problems. Although ${ }^{238} \mathrm{U},{ }^{235} \mathrm{U}$ 
and ${ }^{232} \mathrm{Th}$ themselves are only weakly radioactive, they produce chains of more short-lived radionuclides as they decay, e.g. ${ }^{222} \mathrm{Rn}$ and ${ }^{226} \mathrm{Ra}$. All together, this implies that the U-Th decay series may cause considerable radiation doses. In addition, uranium and thorium are also chemically toxic. Uranium primarily affects the kidneys, and the World Health Organization recommends that the concentration of uranium in drinking water should be below $15 \mu \mathrm{gl}^{-1}$, a limit that is frequently exceeded in uranium-rich areas (Frengstad et al., 2000; Prat et al., 2009). Although thorium is more abundant, it is considered less of a problem due to its lower solubility in natural waters (Langmuir and Herman, 1980). Nevertheless, thorium can be harmful and has been shown to damage the liver function of mice (Kumar et al., 2008). In addition to the natural occurrence of uranium and thorium, human activities such as uranium mining have left a legacy of contamination of soils and groundwater (Hu et al., 2010; Zoriy et al., 2010). The world's boreal forest region have not escaped such disturbances. Both Canada and Russia are major uranium producers, and increasing uranium prices in recent years have boosted the exploration for uranium throughout the world. Issues regarding the long-term biogeochemical cycling of uranium and thorium in the landscape are also becoming increasingly important, as many countries, e.g. Finland and Sweden, are planning to build deep repositories of nuclear waste.

Whereas the spatial and temporal variation in concentrations of uranium has previously been studied in large rivers (Porcelli et al., 1997; Saari et al., 2008), the behaviour of uranium and thorium in small streams is still poorly understood. Hence, the focus of this study is a network of ten streams within a $67 \mathrm{~km}^{2}$ catchment. Including a large number of streams allows a statistical approach to the data, while the spatial resolution also enables a detailed assessment of the role of various landscape types. Small streams are not only important as unique and vibrant ecological environments, but also for the biogeochemical cycles of uranium and thorium on larger scales, because much of the water in big rivers originates from the fine network of small streams that drains the boreal landscape. Yet, the spatiotemporal variability in these streams cannot be deduced from the study of large rivers (Bishop et al., 2008). Often the variability in the stream water chemistry is largest in small $\left(<15 \mathrm{~km}^{2}\right)$ streams (Temnerud and Bishop, 2005). Hence, although little is known about the behaviour of uranium and thorium in headwaters and other small streams, they represent environments that are more likely to be directly affected by mining or deep repositories of nuclear waste, simply because they are much more common than big rivers. Due to their size they are also much more sensitive.

The main objective of this study was to investigate the spatiotemporal variability of uranium and thorium in small boreal streams and, if possible, to explain what factors cause that variability. This will enhance our understanding of how uranium and thorium are transported from terrestrial sys- tems of the boreal forest region and out into aquatic environments. With continuous hydrological measurements and frequent hydrochemical sampling, it was possible to follow the temporal responses of different landscape types and estimate the fluxes of uranium and thorium from each subcatchment. These fluxes were compared to the atmospheric deposition of uranium and thorium in the area, landscape characteristics of the investigated catchments, stream water chemistry and the inventories of uranium and thorium in local soils in order to obtain an improved understanding of the transport and accumulation patterns of uranium and thorium in the boreal landscape.

\section{Material and methods}

\subsection{Site description}

Krycklan is a tributary to one of Sweden's major rivers, the Vindel River (Swedish: Vindelälven). Part of its catchment, the $0.5 \mathrm{~km}^{2}$ Svartberget catchment, has been studied and monitored continuously since 1980 , but environmental research in the area dates back to the early 20th century. In 2002, the Krycklan Catchment Study (KCS) was initiated with intensified sampling of the hydrochemistry in 18 partly nested streams within an area that was expanded to cover $67 \mathrm{~km}^{2}$ of the upper parts of the Krycklan catchment. The Krycklan catchment, which also includes the Vindeln Experimental Forests and is a central part of the Svartberget Longterm Ecological Research site (LTER), has a well-developed research infrastructure. Extensive research in various fields has led to a good, process-based understanding of the catchment and the hydrological connection between streams and soils (Seibert et al., 2009).

The Krycklan catchment is located in northern Sweden $\left(64^{\circ} 14^{\prime} \mathrm{N}, 19^{\circ} 46^{\prime} \mathrm{E}\right)$. The mean annual temperature is $+1.7^{\circ} \mathrm{C}$, and the mean annual precipitation is $625 \mathrm{~mm}$, of which on average $35 \%$ falls as snow. The total annual discharge is about $325 \mathrm{~mm}$, of which approximately one-third leaves the catchment during a few weeks in the spring (Cory et al., 2009). The landscape is dominated by coniferous forests with Scots pine (Pinus sylvestris) and Norwegian spruce (Picea abies). These forests cover $83 \%$ of the total catchment area, and the rest is made up of wetlands (12\%), clear cuttings $(2.1 \%)$, arable land $(0.2 \%)$ and lakes $(0.1 \%)$. These other landscape types may, however, be major constituents of some of the subcatchments (Table 1). Whereas the upper parts of the catchment are dominated by till and peat, large areas of glaciofluvial silt and fine sand deposits are present in its lower parts (Table 1, Fig. 1). The forests are dominated by well-developed podzols, but more organic soils are common in wetter areas. The Quaternary deposits are underlain by gneissic bedrock of svecofennian metasediments, mainly metagraywacke. The stream water is generally characterised by high concentrations of total organic carbon 
Table 1. Area and landscape characteristics of the investigated catchments.

\begin{tabular}{lllllllll}
\hline $\begin{array}{l}\text { Catchment } \\
\text { number }\end{array}$ & Area $\left(\mathrm{km}^{2}\right)$ & Lake $(\%)$ & Forest $(\%)$ & Arable land (\%) & Wetland (\%) & Clear cutting (\%) & Till (\%) & Silt (\%) \\
\hline C1 & 0.6 & 0.0 & 87.2 & 0.0 & 2.7 & 10.1 & 92.8 & 0.0 \\
C2 & 0.1 & 0.0 & 98.7 & 0.0 & 1.3 & 0.0 & 90.6 & 0.0 \\
C4 & 0.2 & 0.0 & 49.6 & 0.0 & 50.4 & 0.0 & 17.1 & 0.0 \\
C5 & 0.8 & 5.8 & 57.5 & 0.0 & 42.5 & 0.0 & 49.5 & 0.0 \\
C6 & 1.3 & 3.7 & 70.7 & 0.0 & 29.3 & 0.0 & 58.4 & 0.0 \\
C7 & 0.5 & 0.0 & 82.7 & 0.0 & 17.3 & 0.0 & 68.0 & 0.0 \\
C9 & 3.1 & 1.5 & 83.8 & 0.0 & 16.1 & 0.1 & 68.9 & 5.9 \\
C14 & 12.6 & 0.1 & 86.4 & 3.0 & 5.7 & 4.2 & 50.2 & 30.8 \\
C15 & 19.7 & 2.0 & 77.6 & 0.2 & 13.7 & 5.0 & 65.7 & 2.0 \\
C16 & 66.8 & 0.7 & 84.0 & 1.9 & 8.6 & 3.7 & 51.9 & 25.7 \\
\hline
\end{tabular}

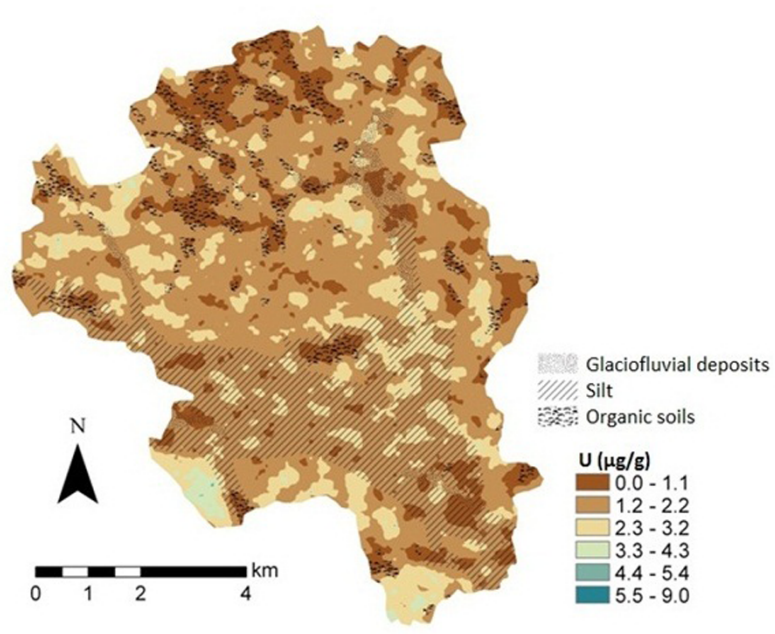

Fig. 1. Concentration of uranium in surface soils and soil type in the Krycklan catchment (SGU, consent Dnr: 30-495/2008).

(TOC) and low $\mathrm{pH}$, but the heterogeneous landscape allows for considerable hydrochemical variability both within and between streams. The average $\mathrm{pH}$ ranges from 4.3 (C4) to 6.4 (C16), and average concentrations of TOC vary from $11 \mathrm{mgl}^{-1}$ (C16) to $31 \mathrm{mgl}^{-1}$ (C4) (Table 2). If the temporal variation also is taken into consideration, the variability is of course even greater. Average concentrations for major ions and other hydrochemical parameters in the investigated streams have been published by Björkvald et al. (2008).

\subsection{Sampling and analyses}

Concentrations of uranium and thorium were monitored in ten partly nested streams within the Krycklan catchment over two years (March 2004-December 2005). The sampling frequency was adjusted depending on the discharge with intensive (up to daily) sampling during the spring flood and sparser (bimestrial) sampling during baseflow conditions.
This was because discharge is an important driver for behind the temporal changes in stream water chemistry and because the large water volumes during hydrological events potentially can transport high amounts of uranium and thorium (Seibert et al., 2009). The investigated subcatchments are denoted $\mathrm{C} 1, \mathrm{C} 2, \mathrm{C} 4, \mathrm{C} 5, \mathrm{C} 6, \mathrm{C} 7, \mathrm{C} 9, \mathrm{C} 14, \mathrm{C} 15$ and $\mathrm{C} 16$, and are shown in Fig. 2. In total, 356 water samples were collected and analysed for uranium and thorium. The water was sampled in acid-washed high density polyethylene bottles, which were rinsed at least three times with stream water. The bottles were completely filled and placed in polyethylene bags directly after sampling. The samples were brought directly from the field to a refrigerator, where they were stored at $4{ }^{\circ} \mathrm{C}$ in complete darkness until further treatment. The water was filtered within $48 \mathrm{~h}$ in a class 100 laminar flow hood using $0.4 \mu \mathrm{m}$ Millipore isotype polycarbonate membrane filters in Millipore SWINNEX-47 filter holders. The filters were rinsed with $50 \mathrm{ml}$ of ultraclean water and then conditioned with $30 \mathrm{ml}$ of sample water. The filtered samples were then acidified with $1 \mathrm{ml}$ suprapure nitric acid per $100 \mathrm{ml}$ of sample, after which they were stored in the refrigerator again. The samples were analysed for ${ }^{232} \mathrm{Th}$ and ${ }^{238} \mathrm{U}$ at Stockholm University using a Thermo Scientific X Series 2 instrument (ICP-MS). Rhodium was added as an internal standard, and SLRS-4 (riverine water; National Research Council; Canada) was used as a control sample. The certified value for uranium in SLRS-4 is $50 \pm 3 \mathrm{ng} \mathrm{g}^{-1}$, and the average of our measurements was $48 \pm 2 \mathrm{ng} \mathrm{g}^{-1}$. For thorium there is no certified value, but Rodushkin et al. (2005) have suggested $17 \pm 2 \mathrm{ng} \mathrm{g}^{-1}$ and Yeghicheyan et al. (2001) $18 \pm 3 \mathrm{ng} \mathrm{g}^{-1}$. Our average was $14 \pm 3 \mathrm{ng} \mathrm{g}^{-1}$ so it comes close to the suggested values. Thus, no significant deviation from the SLRS-4 standard was found. Field blanks were also prepared at each sampling occasion and analysed for control purposes. For uranium the average was $-0.02 \mathrm{ng} \mathrm{g}^{-1}$ and for thorium $0.04 \mathrm{ng} \mathrm{g}^{-1}$. The standard deviation was $0.043 \mathrm{ng} \mathrm{g}^{-1}$ for uranium and $0.16 \mathrm{ng} \mathrm{g}^{-1}$ for thorium. Using three standard deviations as detection limits, this gives $0.13 \mathrm{ng} \mathrm{g}^{-1}$ for uranium and $0.49 \mathrm{ng} \mathrm{g}^{-1}$ for thorium. This 


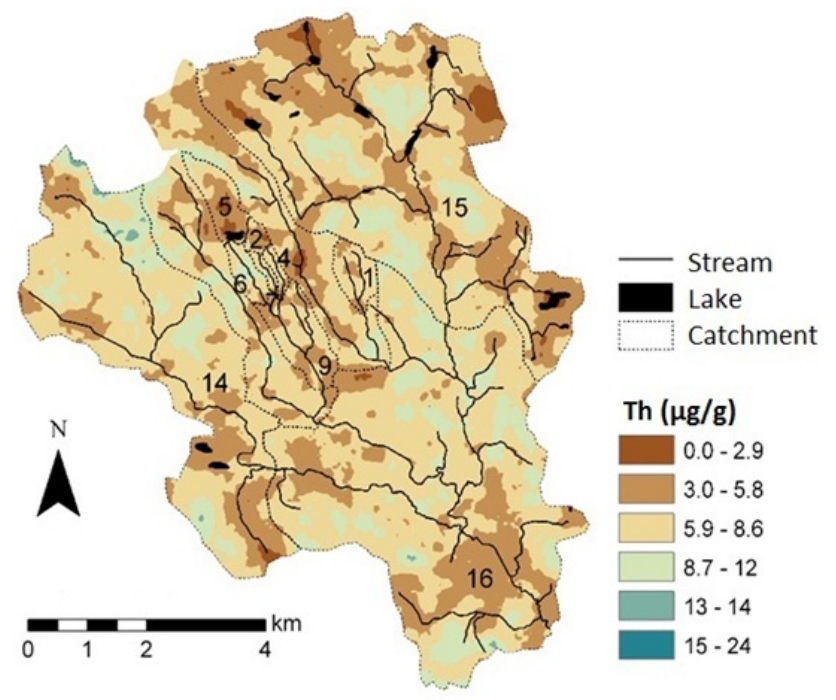

Fig. 2. Concentration of thorium in surface soils in the Krycklan catchment. The investigated subcatchments are indicated by numbers. (SGU, consent Dnr: 30-495/2008).

is well below the lowest observed concentrations in stream water, which were $3.6 \mathrm{ng} \mathrm{g}^{-1}$ for uranium $4.1 \mathrm{ng} \mathrm{g}^{-1}$ for thorium. Further details on the sampling and the analyses can be found elsewhere (Björkvald et al., 2008; Lidman et al., 2011). Precipitation was sampled at the Svartberget LTER in the centre of the Krycklan catchment during 2004 (Klaminder et al., 2006). The samples from each month were mixed to produce monthly volume-weighted averages. The mixed samples were analysed using ICP-MS at the Swedish Defense Research Agency.

Discharge was measured using a $90^{\circ} \mathrm{V}$-notch weir located in $\mathrm{C} 7$ in a heated hut to avoid ice formation in wintertime. The water level was recorded every ten minutes and averaged to produce hourly measurements using a pressure transducer connected to a data logger (Campbell, USA). The discharge for the other subcatchments was estimated by assuming that the specific runoff was the same throughout the entire Krycklan catchment (Laudon et al., 2007). It has been shown that the overall mean differences between streams are less than $12 \%$ and that the streams are highly synchronised during the spring flood (Buffam et al., 2008). To estimate the export of uranium and thorium, daily concentrations were interpolated over the cumulative discharge, multiplied by the daily discharge and summed. $\mathrm{pH}$ and concentrations of TOC, aluminium, silicon and hydrogen carbonate were taken from the regular stream water sampling of the Krycklan Catchment Study (Björkvald et al., 2008).

The concentrations of uranium and thorium in soils were measured by the Swedish Geological Survey (SGU) using airborne gamma spectrometry (Thunblom et al., 2005; Antal Lundin and Bastani, 2007). Flight lines had a separation of $200 \mathrm{~m}$ and the sampling interval was $40 \mathrm{~m}$, resulting in at least 14 observations in each subcatchment and a total of 8433 observations throughout the entire Krycklan catchment. Each observation represents an integrated value over an area described by an ellipse with transverse diameter approximately $200 \mathrm{~m}$, perpendicular to the flight path. Thus, these measurements provide more information about the average concentrations of uranium and thorium than feasibly could be obtained from point measurements (Viscarra Rossel et al., 2010). Kriging was used to interpolate the concentrations of uranium and thorium and to estimate the average concentration within each subcatchment. The values presented for uranium are based on gamma emissions of ${ }^{214} \mathrm{Bi}$, a daughter of ${ }^{222} \mathrm{Rn}$. Due to transport of radionuclides throughout the uranium decay chain, e.g. ${ }^{226} \mathrm{Ra}$ and ${ }^{222} \mathrm{Rn},{ }^{214} \mathrm{Bi}$ may not always be in equilibrium with ${ }^{238} \mathrm{U}$. For control purposes the gamma spectrometric measurements from one of the investigated catchments, $\mathrm{C} 2$, were compared to three soil cores from the same catchment. The total concentrations in these soil cores, as analysed using ICP-MS, ranged from $1.5-2.9 \mu \mathrm{g} \mathrm{g}^{-1}$ for uranium and from $10-22 \mu \mathrm{g} \mathrm{g}^{-1}$ for thorium; the gamma measurements recorded average concentrations of $2.2 \mu \mathrm{g} \mathrm{g}^{-1}$ for uranium and $7.0 \mu \mathrm{g} \mathrm{g}^{-1}$ for thorium with standard deviations of $1.2 \mu \mathrm{g} \mathrm{g}^{-1}$ and $3.4 \mu \mathrm{g} \mathrm{g}^{-1}$, respectively. Hence, the agreement for uranium is good, while the concentration of thorium seems somewhat lower when analysed using gamma spectrometry. However, the deviation is small and could be caused by spatial variability within the catchment. The chemistry and the half-lives of the daughters of ${ }^{232} \mathrm{Th}$ do not suggest similar disequilibria throughout the thorium decay chain as in the uranium decay chain. Therefore, the concentrations of thorium in surface soils should be less uncertain.

\section{Results and discussion}

\subsection{Uranium and thorium in stream water}

Figure 3 shows the concentrations of uranium and thorium in four of the investigated streams: $\mathrm{C} 2$ (a small forested catchment), C4 (a mire outlet), C7 (a small mixed catchment receiving water from both $\mathrm{C} 2$ and $\mathrm{C} 4$ ) and $\mathrm{C} 16$ (a large mixed catchment). Similar graphs for the six remaining streams can be found in the Supplement. See Table 1 for details about the catchments. Compared to the average concentration of uranium reported for Europe $\left(0.32 \mu \mathrm{g}^{-1}\right)$, the concentrations in Krycklan are low (Astrom et al., 2009). It is clear that there are considerable differences between the streams. Particularly low concentrations are found in $\mathrm{C} 4$, a mire outlet, and $\mathrm{C} 5$, a lake outlet. Higher concentrations are found in predominantly forested catchments. It is noteworthy that small forest streams such as C1 $\left(0.60 \mathrm{~km}^{2}\right)$ and $\mathrm{C} 2\left(0.13 \mathrm{~km}^{2}\right)$ during baseflow conditions have similar concentrations of dissolved uranium and thorium as larger catchments like C14 $\left(13 \mathrm{~km}^{2}\right)$ and $\mathrm{C} 16\left(67 \mathrm{~km}^{2}\right)$. As could be expected, mixed catchments 
Table 2. Selected chemical characteristics of the investigated streams and catchments. The fluxes refer to the annual fluxes of each element, and $\mathrm{pH}$ and the concentrations of TOC and hydrogen carbonate are the volumetric averages of each stream. The concentrations of uranium and thorium in soil were determined by airborne gamma spectrometry.

\begin{tabular}{llllllllll}
\hline $\begin{array}{l}\text { Catchment } \\
\text { number }\end{array}$ & $\begin{array}{l}\mathrm{Th} \\
\left(\mathrm{g} \mathrm{km}^{-2}\right)\end{array}$ & $\begin{array}{l}\mathrm{U} \\
\left(\mathrm{g} \mathrm{km}^{-2}\right)\end{array}$ & $\begin{array}{l}\mathrm{TOC} \\
\left(\mathrm{mg} \mathrm{l}^{-1}\right)\end{array}$ & $\begin{array}{l}\mathrm{HCO}_{3}^{-} \\
\left(\mathrm{mg} \mathrm{l}^{-1}\right)\end{array}$ & $\begin{array}{l}\mathrm{pH} \\
-\end{array}$ & $\begin{array}{l}\mathrm{Si} \\
\left(\mathrm{kg} \mathrm{km}^{-2}\right)\end{array}$ & $\begin{array}{l}\mathrm{Al} \\
\left(\mathrm{kg} \mathrm{km}^{-2}\right)\end{array}$ & $\begin{array}{l}\text { Th soil } \\
\left(\mathrm{g} \mathrm{g}^{-1}\right)\end{array}$ & $\begin{array}{l}\mathrm{U} \text { soil } \\
\left(\mu \mathrm{g} \mathrm{g}^{-1}\right)\end{array}$ \\
\hline $\mathrm{C} 1$ & 18 & 16 & 18 & 1.0 & 5.3 & 1500 & 130 & 6.0 & 1.5 \\
C2 & 16 & 17 & 17 & 0.56 & 4.9 & 1300 & 130 & 7.0 & 2.2 \\
C4 & 3.3 & 2.7 & 31 & 0.27 & 4.3 & 580 & 20 & 4.4 & 1.4 \\
C5 & 3.1 & 1.7 & 20 & 0.38 & 4.8 & 700 & 30 & 4.4 & 1.0 \\
C6 & 5.2 & 4.7 & 21 & 1.5 & 5.3 & 940 & 42 & 5.8 & 1.3 \\
C7 & 13 & 12 & 23 & 0.32 & 4.8 & 1100 & 70 & 6.0 & 1.7 \\
C9 & 12 & 11 & 16 & 2.5 & 5.7 & 1200 & 63 & 5.9 & 1.5 \\
C14 & 24 & 30 & 12 & 5.2 & 6.2 & 1200 & 46 & 6.9 & 1.9 \\
C15 & 10 & 12 & 12 & 4.8 & 6.4 & 1100 & 42 & 6.2 & 1.6 \\
C16 & 19 & 27 & 11 & 7.1 & 6.5 & 1200 & 53 & 6.6 & 1.7 \\
\hline
\end{tabular}
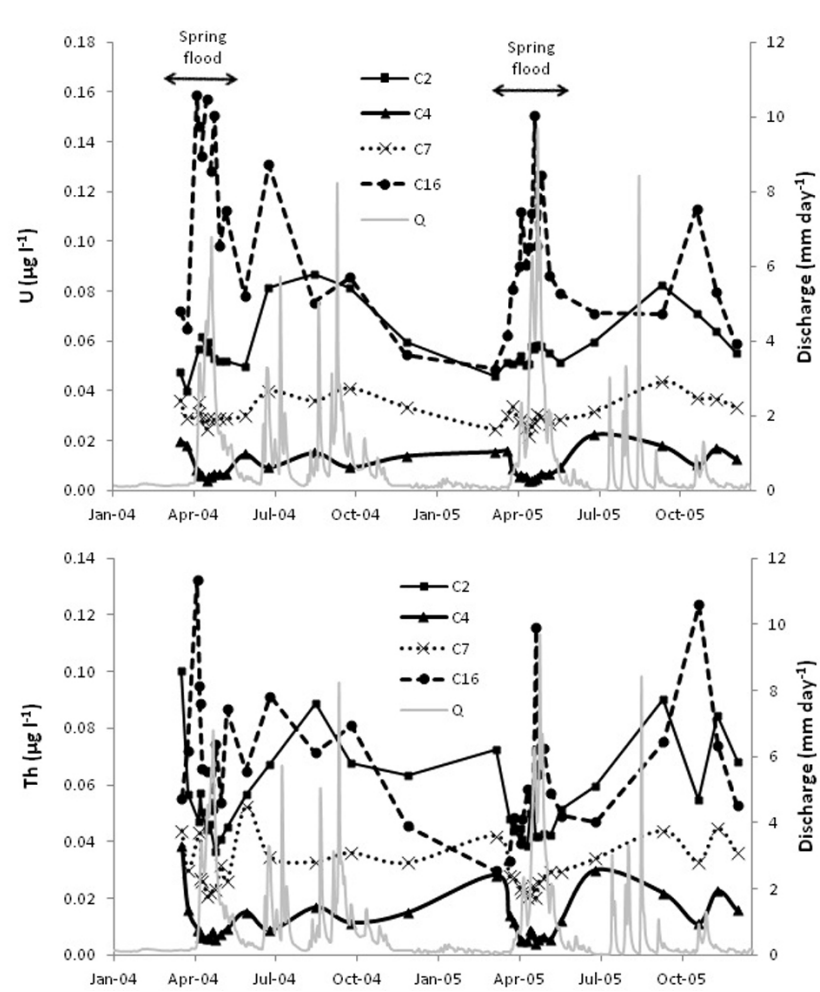

Fig. 3. The concentrations of uranium (upper) and thorium (lower) in four of the investigated streams: C2 (small forested catchment), C4 (mire outlet), C7 (small mixed catchment) and C16 (large mixed catchment). The discharge $(\mathrm{Q})$ is shown in grey.

like $\mathrm{C} 7$, which receives water from both $\mathrm{C} 2$ (forest) and $\mathrm{C} 4$ (mire), have intermediate concentrations of uranium and thorium.

Generally, the concentrations of uranium and thorium tend to co-vary - both within streams and between streams (Fig. 3). Based on all samples from all streams, the correlation coefficient between the concentrations of uranium and thorium is $r=0.84$ ( $n=356, p<0.0001)$, not accounting for possible autocorrelation within the streams. Their similar behaviour suggests that uranium and thorium have a common source and that their release into the streams is largely controlled by the same processes. Figure 3 also shows that there are considerable differences in the temporal variation between the streams, for instance in their responses to the spring flood. At the mire outlet, $\mathrm{C} 4$, there is a sharp decline in the concentrations of both uranium and thorium when the spring flood sets in. The concentrations also tend to decrease in many of the smaller streams. In C16, on the other hand, a clear increase of the concentrations can be observed during the spring flood. Since none of the contributing subcatchments evidently is responsible for this increase, there must be an outflow of groundwater with high concentrations of uranium and thorium in the lower parts of C16. This could be related to the silt deposits that dominate the lower parts of the catchment (Fig. 1) or possibly a result of deeper groundwater pathways in larger catchments.

There are significant correlations at the $95 \%$ confidence level in the concentrations of both thorium and uranium between some of the streams, although the correlations are weak in most cases. Generally, uranium is more variable between the streams than thorium, as demonstrated by the wider range for the fluxes of uranium in Table 2. There is only one case where the concentrations of uranium in one stream can explain more than $50 \%$ of the variance in another stream. In contrast to what could be expected, this does not occur in any of the streams that are directly connected, but in $\mathrm{C} 1$ and $\mathrm{C} 7\left(r^{2}=0.69\right)$. For thorium there are five cases where the coefficient of determination exceeds 0.5. All of them involve only the smaller subcatchments $\left(<1.3 \mathrm{~km}^{2}\right)$. Overall, the modest or non-significant correlations between the streams suggest that it is not generally possible to extrapolate knowledge of the temporal variation in the concentrations of uranium and thorium in one stream to another nearby stream. The large variability agrees with previous 
studies, which have identified uranium as one of the elements whose concentration varies the most in wetland-influenced streams (Kerr et al., 2008).

Hydrological processes have been demonstrated to drive much of the variability in water chemistry of these streams (Köhler et al., 2009a; Seibert et al., 2009). This is also likely to be the case for uranium and thorium, but in general there are no simple correlations between the discharge and the concentrations of uranium and thorium. In C16 there is a weak tendency that the concentrations of uranium increase with increasing discharge. The opposite occurs at the mire outlet (C4), where Lidman et al. (2012) previously have observed decreasing concentrations with increasing discharge. In $\mathrm{C} 4$ the decreasing concentrations of uranium and thorium during the spring flood are due to dilution by meltwater. Using ${ }^{18} \mathrm{O}$ it has been demonstrated that a large proportion of the water in $\mathrm{C} 4$ is event water, i.e. recently melted snow (Laudon et al., 2004). Since the concentrations of uranium and thorium in precipitation are low (see below), stream water concentrations will consequently decrease during the spring flood. In forest-dominated catchments like $\mathrm{C} 2$, the hydrology functions differently, and hardly any event water reaches the stream during the snowmelt period (Laudon et al., 2004). Consequently, there will be no comparable dilution by meltwater. This is generally the case for forest streams, where surface runoff is rare. Instead old pre-event water from the riparian soils is pushed out into the stream, and the response of the stream will depend on the concentrations of uranium and thorium in the pre-event water that is mobilised during the spring flood. In C2 there is a decrease in both uranium and thorium, which depends on lower concentrations of uranium and thorium the more superficial soil layers that are activated by a so-called transmissivity feedback mechanism during the spring flood (Seibert et al., 2009). In mixed catchments, variations will be influenced by the different characteristics of the landscape, e.g. uranium and thorium exported from mires and forests mixing in different proportions.

\subsection{Atmospheric deposition of uranium and thorium}

During 2004 thorium concentrations in precipitation varied from below the detection limit $\left(<0.06 \mathrm{ngl}^{-1}, n=3\right)$ to $1.74 \mathrm{ng}^{-1}$ in monthly bulked samples. Uranium concentrations ranged from 0.03 to $1.23 \mathrm{ng}^{-1}$. No clear seasonal trends could be observed for either uranium or thorium. The deposition was estimated to be $0.22 \mathrm{~g} \mathrm{~km}^{-2} \mathrm{a}^{-1}$ for thorium and $0.17 \mathrm{~g} \mathrm{~km}^{-2} \mathrm{a}^{-1}$ for uranium. During 2004, a total of $607 \mathrm{~mm}$ of precipitation was measured at the meteorological station within the Krycklan catchment. This is close to the annual average precipitation for 1988-2008 (598 mm). Therefore, these estimates of the deposition are not biased due to anomalous precipitation.

\subsection{Fluxes of dissolved uranium and thorium}

The differences in stream water concentrations of uranium and thorium in the investigated catchments will inevitably also be reflected in different fluxes. Our estimates indicate that the export of dissolved thorium varies between 3.2 and $24 \mathrm{~g} \mathrm{Th} \mathrm{km}^{-2} \mathrm{a}^{-1}$ (Table 2). The highest export was observed from one of the silt-rich subcatchments, C14, whereas the lowest export was observed at the lake outlet, C5, and the mire outlet, C4. Hence, C14 exported more than seven times more thorium than $\mathrm{C} 5$. The variation was even more pronounced for uranium. Here, C14 exported $30 \mathrm{~g} \mathrm{U} \mathrm{km}^{-2} \mathrm{a}^{-1}$, whereas C5 exported only $1.7 \mathrm{~g} \mathrm{U} \mathrm{km}^{-2} \mathrm{a}^{-1}$ (Table 2). This implies that the flux varies by almost a factor 18 only within the $67 \mathrm{~km}^{2}$ of the Krycklan catchment.

It is evident that export of both uranium and thorium greatly exceeds atmospheric input; even in the subcatchments with the lowest export, atmospheric deposition does not contribute with more than $10 \%$ of the total export at the most. Since much of the deposited uranium and thorium could be expected to accumulate in top soils, weathering of mineral soils and, possibly, bedrock must be the dominating source of uranium and thorium in the streams.

Comparing the export of uranium and thorium with their respective abundance in the local soils, it is clear that there is a preferential export of uranium. In the nearby Kalix River (Swedish: Kalixälven), the U/Th ratios in river water were about 40 times higher than the ratio in detrital matter (Andersson et al., 1998). The differences are not that pronounced in Krycklan: while the exports of uranium and thorium are approximately the same, thorium is approximately four times more common than uranium in surface soils. Based only on stream water analyses, it is not possible determine the reason for the lower export of thorium in this case, but there are several possibilities, e.g. lower weathering rates of thoriumbearing minerals, precipitation of secondary thorium minerals or preferential sorption of thorium to some phase in the soils.

Attempts to estimate the export of uranium from the world's major rivers have revealed large spatial differences also on the global scale. Among the world's ten rivers with the highest discharge, the export of uranium ranges from $3.0 \mathrm{~g} \mathrm{U} \mathrm{km}^{-2} \mathrm{a}^{-1}$ in the Paraná River to $950 \mathrm{~g} \mathrm{U} \mathrm{km}^{-2} \mathrm{a}^{-1}$ in the Brahmaputra River. The export of uranium from the Krycklan catchment is comparable to, for example, the Amazon River $\left(29 \mathrm{~g} \mathrm{U} \mathrm{km}^{-2} \mathrm{a}^{-1}\right)$, the Zaire River $\left(18 \mathrm{~g} \mathrm{U} \mathrm{km}^{-2} \mathrm{a}^{-1}\right)$ and the Orinoco River $\left(30 \mathrm{~g} \mathrm{U} \mathrm{km}^{-2} \mathrm{a}^{-1}\right)$, although European rivers generally tend to export more than $100 \mathrm{~g} \mathrm{U} \mathrm{km}^{-2} \mathrm{a}^{-1}$ (Dunk et al., 2002). The nearby Kalix River has been estimated to export $80 \mathrm{~g} \mathrm{U} \mathrm{km}^{-2} \mathrm{a}^{-1}$, but, in addition to the fact that it is much larger than the streams in this study, its catchment also includes alpine regions and different types of bedrock (Andersson et al., 1998). 


\subsection{Concentrations of uranium and thorium in surface soils}

The concentrations of uranium and thorium in surface soils throughout the Krycklan catchment are shown in Figs. 1 and 2 , and the average concentrations for each of the investigated subcatchments can be found in Table 2 . The average concentrations of uranium in the investigated catchments ranged from $1.0 \pm 1.3 \mu \mathrm{gg}^{-1}$ (C5) to $2.2 \pm 1.2 \mu \mathrm{g} \mathrm{g}^{-1}$ (C2). The corresponding concentrations for thorium ranged from $4.4 \pm 2.7 \mu \mathrm{g} \mathrm{g}^{-1}$ (C4) and $4.4 \pm 3.4 \mu \mathrm{gg}^{-1}$ (C5) to $7.0 \pm 3.4 \mu \mathrm{g} \mathrm{g}^{-1}(\mathrm{C} 2)$. Overall, the average concentrations in the entire Krycklan catchment $(\mathrm{C} 16)$ were $1.7 \pm 1.4 \mu \mathrm{g} \mathrm{g}^{-1}$ for uranium and $6.6 \pm 3.2 \mu \mathrm{g} \mathrm{g}^{-1}$ for thorium, indicating that the levels of uranium and thorium in Krycklan are ca. $30 \%$ lower than the estimated average concentrations in continental crust (Wedepohl, 1995). As suggested by Fig. 1, low concentrations of uranium are associated with the occurrence of organic soils, e.g. wetlands. The average concentration of uranium in forest soils was $1.8 \pm 1.4 \mu \mathrm{g} \mathrm{g}^{-1}(n=7406)$, while it was only $0.74 \pm 0.92 \mu \mathrm{g} \mathrm{g}^{-1}$ in wetlands $(n=680)$. A similar difference was observed for thorium, for which the average concentration in forest soils was $6.9 \pm 3.1 \mu \mathrm{g} \mathrm{g}^{-1}$, compared to $3.4 \pm 2.6 \mu \mathrm{g} \mathrm{g}^{-1}$ in wetlands. The surface soil concentrations of uranium and thorium in the investigated catchments are both negatively correlated to the lake and wetland coverage: $r=-0.73(p<0.05)$ for uranium and $r=$ $-0.93(p<0.001)$ for thorium. Hence, the extension of wetlands seems to explain most of the differences in the soil concentrations of uranium and thorium between the investigated catchments, indicating that the mineral soils are relatively homogeneous with respect to uranium and thorium on the catchment scale. There are probably some uncertainties in these numbers, since peat and minerals have different absorptive properties with respect to gamma radiation. Furthermore, when analyzing peat samples from the mire in C4, Lidman et al. (2012) found pronounced disequilibria between ${ }^{226} \mathrm{Ra}$ and ${ }^{238} \mathrm{U}$. This suggests that the concentrations of uranium in wetlands may be somewhat exaggerated by airborne gamma spectrometry, which may also explain why the correlation for uranium is weaker. Nevertheless, the estimations for the wetlands based on airborne gamma spectrometry agree reasonably well with estimations of the average concentrations presented by Lidman et al. (2012): 0.4$1.6 \mu \mathrm{g} \mathrm{g} \mathrm{g}^{-1}$ and 1.2-4.9 $\mu \mathrm{g} \mathrm{Th}^{-1}$.

\subsection{What controls the fluxes of uranium and thorium?}

Understanding the underlying processes governing the highly variable fluxes of uranium and thorium in the boreal landscape is central for any attempts predict the long-term fate of these elements and reliably assess their impact both from a toxicological and a radioecological perspective. In addition to the soil concentrations of uranium and thorium, Table 2 also presents some selected parameters describing the stream chemistry, e.g. $\mathrm{pH}, \mathrm{TOC}$, hydrogen carbonate, $\mathrm{Al}$ and $\mathrm{Si}$. As can be seen in Table 3, many of the listed parameters are correlated to the fluxes of uranium and thorium, but they are also in many cases correlated to one another. Hence, there is an obvious risk of confounding, when trying to identify the true causes behind the variability. It is important to keep in mind that correlation does not imply causation.

Astrom et al. (2009) have previously investigated the relationship between the concentrations of uranium in streams and groundwater and the concentrations in local soils throughout Finland and northwest Russia. In Precambrian areas Astrom et al. (2009) could demonstrate a significant, albeit rather weak, correlation between the concentration of uranium in surface soils and the concentration in stream water $\left(r_{\mathrm{s}}=0.45, n=660\right)$. However, in Phanerozoic areas in Russia no such correlation was found. Instead, the concentration of uranium in stream water was correlated to the concentration of hydrogen carbonate $\left(r_{\mathrm{s}}=0.66, n=674\right)$ and the concentration of calcium $\left(r_{\mathrm{s}}=0.80\right)$. Both correlations seem reasonable, since they point to factors that could be expected to increase the mobilization of uranium: higher concentrations of uranium in the soils could potentially lead to higher concentrations of uranium in runoff, whereas high concentrations of carbonate would favour the formation of uranyl-carbonate complexes, thereby increasing the mobility of uranium. The investigations of Astrom et al. (2009) operate on much larger scales, using discrete soil samples and single observations of the stream water chemistry, but similar correlations between concentrations in soils and fluxes can be found in Krycklan: $r=0.68(p<0.05)$ for uranium and $r=0.84(p<0.01)$ for thorium. In relation to Table 3 we should also point out that there is a slight bias in the dataset, since some of the streams are nested. If the dependent streams (C6, C7, C9 and C16) are excluded, the correlations will in most be cases very similar to those obtained using the full dataset. The only major differences are that the soil concentrations of uranium are not correlated to either the lake and wetland coverage or to the fluxes of uranium, when using only the independent catchments. Thus, the relationship between the fluxes of uranium and the soil concentrations of uranium is weak - if there indeed is one. Note that the fluxes of uranium instead are more strongly correlated to the soil concentrations of thorium: $r=0.83(p<0.01)$. However, as previously observed, the difference in the soil concentrations of thorium between the investigated catchments is almost entirely explained by the extension of wetlands, so it may not even be the reason behind the variable fluxes of thorium. One reason is that it does not explain why the spatial variability is so large. For instance, if we compare C2 to the adjacent $\mathrm{C} 4$, the soil concentration of thorium drops by $40 \%$ from $7.0 \mu \mathrm{g} \mathrm{g}^{-1}$ to $4.4 \mu \mathrm{gg}^{-1}$, while the flux drops by $80 \%$ from $16 \mathrm{~g} \mathrm{~km}^{-2} \mathrm{a}^{-1}$ to $3.3 \mathrm{~g} \mathrm{~km}^{-2} \mathrm{a}^{-1}$. Hypothetically, this could be explained by differences in mineralogy, but there are no observations to support such an assumption. On the contrary, airborne gamma spectrometry suggests that 
Table 3. Correlation coefficients between selected parameters from Tables 1 and 2. WL stands for the wetland and lake coverage. Unless otherwise stated the correlations are significant at the $95 \%$ significance level $(p<0.05)$.

\begin{tabular}{llllllllll}
\hline & $\mathrm{Th}$ & $\mathrm{U}$ & $\mathrm{TOC}$ & $\mathrm{HCO}_{3}^{-}$ & $\mathrm{pH}$ & $\mathrm{Si}$ & $\mathrm{Al}$ & $\mathrm{Th}$ soil & $\mathrm{U}$ soil \\
\hline $\mathrm{U}$ & $0.96^{* *}$ & - & - & - & - & - & - & - & - \\
\hline $\mathrm{TOC}$ & -0.67 & -0.73 & - & - & - & - & - & - & - \\
\hline $\mathrm{HCO}_{3}^{-}$ & - & 0.73 & $-0.79^{*}$ & - & - & - & - & - & - \\
\hline $\mathrm{pH}$ & - & 0.70 & $-0.91^{* *}$ & $0.94^{* *}$ & - & - & - & - & - \\
\hline $\mathrm{Si}$ & $0.82^{*}$ & 0.69 & -0.65 & - & - & - & - & - & - \\
\hline $\mathrm{Al}$ & - & - & - & - & - & $0.81^{*}$ & - & - & - \\
\hline $\mathrm{Th}$ soil & $0.84^{*}$ & $0.83^{*}$ & -0.72 & - & - & $0.83^{*}$ & - & - & - \\
\hline $\mathrm{U}$ soil & 0.69 & 0.68 & - & - & - & - & - & $0.83^{*}$ & - \\
\hline $\mathrm{WL}$ & $-0.89^{* *}$ & $-0.80^{*}$ & 0.73 & - & - & $-0.97^{* *}$ & -0.74 & $-0.93^{* *}$ & -0.73 \\
\hline
\end{tabular}

Significance codes: $* p<0.01 ; * * p<0.001$.

the soils are comparatively homogeneous on the catchment scale. Hence, the spatial variability in the fluxes of uranium and thorium is probably not caused by differences in soil concentrations of uranium and thorium in the soils. However, on large scales, as in the study of Astrom et al. (2009), it still seems reasonable that the soil concentrations could play a significant role, since the soil concentrations of both uranium and thorium are known to vary considerably on regional scales.

As for the role of carbonates, the flux of uranium, but not that of thorium, is correlated to the concentration of hydrogen carbonate in the stream water $(r=0.73, p<0.05)$. This could suggest that carbonate complexes play an important role for the transport of uranium in the lower parts of the Krycklan catchment (Table 2). However, thermodynamic modelling of the speciation of uranium using Visual MINTEQ 3.0 does not show any significant formation of carbonate complexes in the stream water (Gustafsson, 2012). Hence, the hypothesis that mobile carbonate complexes drive the spatial variability of the fluxes of uranium in Krycklan must be dismissed. However, formation of carbonate complexes may still be important on larger scales, especially when calcite-rich areas are included (Astrom et al., 2009).

Kalin et al. (2005) have shown that $\mathrm{pH}$ may exert a strong control on the solubility of uranium. Indeed, there is a positive correlation between $\mathrm{pH}$ and the flux of uranium (but not thorium) in the Krycklan catchment $(r=0.70, p<0.05)$, which is consistent with the results of Kalin et al. (2005). However, according to Visual MINTEQ 3.0 the difference in $\mathrm{pH}$ between the streams is not enough to alter the speciation of uranium more than marginally. Hence, it does not seem likely that the fluxes of uranium are controlled by $\mathrm{pH}$-driven solubility. Instead, Visual MINTEQ 3.0 suggests that more than $96 \%$ of the uranium in all streams is bound to TOC.
This agrees well with measurements from the nearby Kalix River, showing that a large portion of the uranium (30-90\%) is transported by organic colloids (Porcelli et al., 1997). Similarly, it has also been shown that rare earth elements are associated with TOC in the Krycklan catchment, and that iron colloids seem to be absent - at least in the headwaters (Köhler et al., 2009b). Therefore, it is likely that TOC also plays a central role for the transport of uranium and thorium in the Krycklan catchment, especially since the concentrations of TOC are higher than in the Kalix River. Thermodynamic constants for the Th-TOC interactions are currently not available in Visual MINTEQ, but thorium probably has an even stronger affinity for TOC.

Given that the transport of both uranium and thorium appears to be so dependent on TOC as a carrier, it would be reasonable to propose that the fluxes of these elements could be controlled by the availability of TOC. However, Table 3 shows that the correlations to TOC are negative. Thus, increasing levels of TOC are associated with decreasing fluxes of uranium and thorium. The hypothesis that there is a carrier limitation must therefore be rejected. The negative correlations probably hark back to the fact that wetlands are a major source of TOC to the streams, while the primary source of uranium and thorium is mineral soils. Astrom et al. (2009) argue that the lack of correlation between uranium and TOC in their dataset would imply that TOC cannot be the main carrier of uranium. However, this would be true only if there were a carrier limitation. Hence, their observations do not contradict the conclusions of Porcelli et al. (1997) that much of the uranium in boreal rivers is transported by TOC.

While there are no signs of a carrier limitation, there are instead signs of a source limitation in these systems. Much of the correlations that have been discussed above seem to be related to the extension of wetlands (Table 3). The lake 


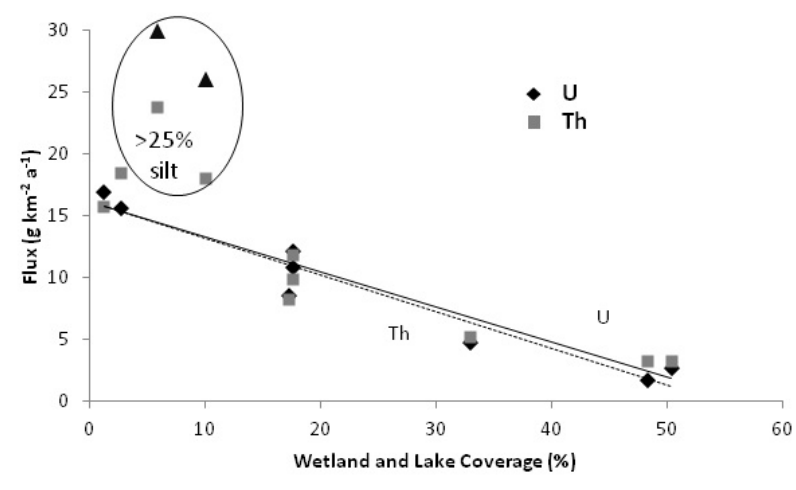

Fig. 4. Fluxes of uranium and thorium as a function of the wetland and lake coverage. The regression lines are based only on the catchments with less than $6 \%$ silt. The excluded catchments (C14 and C16) contain more than $25 \%$ silt - see details in the text.

and wetland coverage is negatively correlated to the fluxes of both uranium $(r=-0.80, p<0.01)$ and thorium $(r=-0.89$, $p<0.001)$, suggesting that the wetlands may be limiting the export of uranium and thorium (Fig. 4). A similar dependence on the wetlands has previously been observed for the stream water concentrations of aluminium during the spring flood (Cory et al., 2006), although it does not seem to be valid on a whole-year basis (Table 3 ). Figure 4 shows that the large silt-rich catchments, C14 and C16, deviate somewhat from the general pattern by exhibiting unexpectedly high fluxes of uranium and thorium. Using multiple linear regression without interaction terms, including the wetland and lake coverage as one independent variable and the silt coverage as the other, it is possible to explain $98 \%$ of the variance in the export of uranium $(p<0.001)$ and $93 \%$ of the variance in the export of thorium $(p<0.001)$. The export of uranium, $\mathrm{U}\left(\mathrm{g} \mathrm{km}^{-2} \mathrm{a}^{-1}\right)$, can be estimated as

$\mathrm{U}=16-0.29 \mathrm{WL}+0.52 \mathrm{~S}$

where S denotes the silt coverage (\%) and WL the combined wetland and lake coverage (\%). The corresponding model for the export of thorium, Th $\left(\mathrm{g} \mathrm{km}^{-2} \mathrm{a}^{-1}\right)$, is

$\mathrm{Th}=16-0.28 \mathrm{WL}+0.26 \mathrm{~S}$.

It is interesting that the two equations are almost identical, with the exception that the export of uranium is more influenced by the silt. Lakes were added to the wetlands in this case, since they are expected to behave more like wetlands than forest soils in the sense that they limit the contact with mineral soils, which could provide the streams with uranium and thorium. However, the area of lakes in the Krycklan catchment is too small to draw any statistically certain conclusions concerning the role of lakes (Table 1).

Exactly what process the silt represents in these two equations is not entirely clear. One possibility is that the weathering rates of uranium and thorium for mineralogical reasons are higher in the silt areas, but it is also possible that the mobilisation of these metals somehow is facilitated by the local chemical conditions. For instance, Table 2 shows that the fluxes of $\mathrm{Al}$ from the larger catchments are lower than from small forest-dominated catchment, possibly due to precipitation of $\mathrm{Al}(\mathrm{OH})_{3}$ as the $\mathrm{pH}$ increases. This could favour the mobilisation of trace elements like uranium and thorium by making more binding sites on the TOC available. The concentration of hydrogen carbonate is also higher in the larger catchments, and although this may not affect the speciation of uranium and thorium in the stream water, it may still be important for the transport in the groundwater, where the concentrations of TOC usually are low.

As for the wetlands, their impact on the fluxes is probably twofold. To begin with wetlands will decrease the area of exposed mineral soils. Since the mineral soils are the major source for both uranium and thorium in these systems, this will lead to lower fluxes from wetland-dominated catchments. The effect on the fluxes should be equal to the decrease in mineral soils; i.e. replacing $50 \%$ of the mineral soils in a catchment by wetlands - ceteris paribus - should decrease the amount of uranium and thorium released by weathering by approximately $50 \%$. In addition, it is wellknown that uranium can accumulate in peat (Shotyk, 1988; Owen and Otton, 1995; Krachler and Shotyk, 2004; Zaccone et al., 2007; Schöner et al., 2009). Natural or constructed wetlands are also commonly used to remove trace elements like uranium from contaminated water, e.g. in the mining industry (Sheoran and Sheoran, 2006; Kröpfelová et al., 2009). The behaviour of thorium in wetlands has been less widely studied, but it has been reported that thorium can also accumulate in peat (Krachler and Shotyk, 2004). Furthermore, Lidman et al. (2012) have observed accumulation of both uranium and thorium along the edges of the mire in $\mathrm{C} 4$. Integrating over the entire history of this mire, the accumulated amounts seem to be consistent with what is predicted by this study (Lidman et al., 2012). Comparing $C 2$ and $C 4$ again, the accumulation of uranium and thorium in wetlands explains why a $50 \%$ decrease in the area of mineral soils does not lower the fluxes by $50 \%$, but rather by $80-90 \%$ (Table 2 ).

The results of this study do not provide much insight into what mechanisms control the accumulation of uranium and thorium in wetlands, but the fact that the retention is almost identical for both elements suggests that they are controlled by the same process (Eqs. 1 and 2). This would indicate that binding to organic matter is the dominating process. That would also be in agreement with investigations of uranium in natural wetlands in Germany, where most of the uranium was found to be associated with organic matter and no signs of precipitation or association with mineral surfaces could be found (Schöner et al., 2009). Reduction of U(VI) to U(IV) and subsequent precipitation would also be a potential retention mechanism for uranium. Measurements in $\mathrm{C} 4$ indicate that the redox potential may be reducing enough to allow reduction of uranium in parts of the mire, but this does 
not necessarily imply that uranium is precipitated, especially given the high concentrations of TOC in the mire water (10$50 \mathrm{mg}^{-1}$ ) (Sirin et al., 1998; Lidman et al., 2012).

\subsection{Quantifying the retention of uranium and thorium in wetlands}

The observation that the spatial variability of the fluxes of uranium and thorium in the Krycklan catchment is controlled by the wetlands provides an opportunity to quantify the accumulation of uranium and thorium on the landscape scale. Since the release of uranium and thorium from the silt-rich areas is higher than from till-areas and few wetlands are located in the silt-areas, we will focus on the till-dominated catchments in the following in order not to overestimate the input of uranium and thorium to mires. Hence, when excluding C14 and C16, a linear regression between the flux of uranium and the lake and wetland coverage indicates that the relative export of uranium, compared to a completely forested catchment, $\mathrm{U}_{\text {rel }}(\%)$, can be predicted as $\left(R^{2}=0.94\right.$, $p<0.001)$

$U_{\text {rel }}=100-1.84 \mathrm{WL}$.

As previously, WL denotes the wetland and lake coverage $(\%)$. The corresponding model for the relative export of thorium, $\mathrm{Th}_{\text {rel }}(\%)$, is $\left(R^{2}=0.88, p<0.001\right)$

$\mathrm{Th}_{\mathrm{rel}}=100-1.75 \mathrm{WL}$.

In both cases the extrapolated export from a completely forested catchment has been used to normalise the equations. Equations (3) and (4) indicate that, for each percent of wetlands that is replacing mineral soils in a catchment, the export of uranium and thorium decreases by approximately $1.8 \%$, slightly more for uranium and slightly less for thorium. For comparison, the same approach is used for another weathering product, silicon. The relative export of silicon, compared to a completely forested catchment, $\mathrm{Si}_{\text {rel }}(\%)$, can be described as $\left(R^{2}=0.94, p<0.001\right)$

$\mathrm{Si}_{\text {rel }}=100-1.16 \mathrm{WL}$.

Equation (5) suggests that the fluxes of silicon in the boreal landscape are also controlled by the wetlands, but that the effect of wetlands is less pronounced than for uranium and thorium. Although the biogeochemical cycling of silicon is complex due to its biological importance, it does not have the same affinity for organic matter as uranium and thorium (Engstrom et al., 2010). We therefore propose that the difference between silicon on one hand and uranium and thorium on the other hand depends on the fact that uranium and thorium are accumulated in peat to a higher degree than silicon. The slope of the regression line for silicon is close to 1 , showing that replacing a certain fraction of the mineral soils in a catchment by wetlands - ceteris paribus - would cause the flux of silicon to decrease by almost the same fraction. For uranium and thorium there would, however, be an additional decrease by roughly $0.8 \%$ in the fluxes for each percent of wetlands that is present in a catchment. This additional decrease would then correspond to the accumulation in the peat.

In reality, it is hardly the mire coverage per se that causes the decreased export of uranium and thorium, but rather the fraction of stream water flowing through significant amounts of peat in order to reach the stream channel. For instance, if a catchment has a mire coverage of $50 \%$, with all mineral soils located upstream from the mire, it would probably export less thorium than a catchment with the same mire coverage but only half of the mineral soils located upstream from the mire and the rest downstream. However, in C4 the sampling site is located close to the outlet of a mire, and in $\mathrm{C} 5$ the sampling site is close to the outlet of a lake, which is almost entirely surrounded by peat. Thus, it can be estimated that almost all water in these two streams must have passed through considerable volumes of peat (or possibly to some extent organic sediments) in order to reach the stream. If we assume that the export of uranium and thorium from the mineral soils further upstream in these two catchments is comparable to other till soils in the Krycklan catchment, as suggested by the gamma spectrometric measurements, Eqs. (1) and (2) can be used to estimate the input of uranium and thorium into the mires in $\mathrm{C} 4$ and $\mathrm{C} 5$. Thus, by comparing the estimated input to the measured output, it seems that at least $65-80 \%$ of the uranium and $55-65 \%$ of the thorium that enter a wetland could be expected to accumulate within it.

\section{The role of wetlands in the boreal landscape}

The capability of wetlands to accumulate above all uranium is well-known (see above). These results further demonstrate that wetlands are the major controlling factor behind the transport of uranium and thorium in small boreal streams and that the accumulation of uranium and thorium in wetlands is both systematic and predictable on the landscapescale (Eqs. 3 and 4). It has been discussed whether mires could also constitute a major source of uranium in the boreal landscape during the spring flood (Andersson et al., 1995; Porcelli et al., 1997). This hypothesis has been questioned previously, since it is unable to explain the ${ }^{234} \mathrm{U} / 238 \mathrm{U}$ ratio of river water (Porcelli et al., 1997). Furthermore, this study shows that the concentration of uranium from the monitored mire outlet at $\mathrm{C} 4$ decreases drastically when the spring flood sets in, but that there still is an increase further downstream (C16). It seems clear that the mires within the Krycklan catchment are not sources of uranium during any part of the year, but sinks. The same applies to thorium. OlivieLanquet et al. (2001) have proposed that the concentration of DOC could be a key factor for deciding whether a wetland will act as a sink or a source for trace elements. Provided that the wetland is not being drained or disturbed in some way, we see little reason to expect boreal mires to act as sources for 
uranium and thorium. The negative correlation between TOC and the fluxes of uranium and thorium clearly shows that the release of uranium and thorium from wetlands is not limited by the availability of TOC (Table 3). Lidman et al. (2012) have also shown that the mire in $\mathrm{C} 4$ is far from being saturated with respect to uranium and thorium and that the accumulation of these elements could be expected to continue for a long time to come.

To conclude, the present study has demonstrated that there is a considerable variability in the spatiotemporal dynamics of uranium and thorium in small boreal streams. However, there are clear trends in the annual export of both uranium and thorium, depending mainly on the forest-mire gradient. Thus, our results emphasise the role of the landscape for controlling the transport of uranium and thorium in boreal catchments. Given the appreciable differences in the concentrations of uranium and thorium in the bedrock and Quaternary deposits throughout the boreal region, it is doubtful whether the forest-mire gradient would be as decisive for the fluxes of uranium and thorium on regional scales as it is in the Krycklan catchment. Yet, there are good reasons to assume that the fundamental role of wetlands as sinks for uranium and thorium is valid over large areas, possibly with the exception of calcite-rich areas. The consequences of the accumulation are far-reaching, since mires and other types of wetlands are so common throughout the boreal region. Peatlands across the North American and Eurasian boreal forest zones are estimated to contain one-third of the world's organic carbon in soils (Gorham, 1991), which implies that the potential for accumulation of uranium and thorium is substantial. As an example, more than $20 \%$ of Sweden is estimated to be covered by wetlands (Nilsson et al., 2001). Assuming that this estimate $(20 \%)$ is valid throughout the boreal zone, Eqs. (3) and (4) suggest that wetlands may reduce the fluxes of uranium and thorium from the boreal landscape to major rivers, lakes and oceans by as much as $30-40 \%$. It also implies that there is a considerable redistribution of uranium and thorium within the boreal landscape - from mineral soils to wetlands. If the primary immobilisation mechanism behind the accumulation of uranium and thorium indeed is binding to organic matter, similar patterns are also likely to occur for many other elements with a high affinity for organic matter.

\section{Supplementary material related to this article is available online at: http://www.biogeosciences.net/9/ 4773/2012/bg-9-4773-2012-supplement.pdf.}

Acknowledgements. We thank all colleagues in the Krycklan Catchment Study, who have contributed to this study. FL was funded by the Swedish Nuclear Fuel and Waste Management Company (SKB). Funding from VR, Formas, Kempe and other sources to KCS is also greatly appreciated.

Edited by: C. Woulds

\section{References}

Andersson, P., Wasserburg, G., Chen, J., Papanastassiou, D., and Ingri, J.: U-238-U-234 and Th-232-Th-230 in the Baltic Sea and in river water, Earth Planet. Sci. Lett., 130, 217-234, 1995.

Andersson, P., Porcelli, D., Wasserburg, G., and Ingri, J.: Particle transport of U-234-U-238 in the Kalix River and in the Baltic Sea, Geochim. Cosmochim. Acta, 62, 385-392, 1998.

Antal Lundin, I. and Bastani, M.: Analysis of petrophysical properties of some granitoids in Sweden, J. Appl. Geophys., 62, 74-87, doi:10.1016/j.jappgeo.2006.09.002, 2007.

Astrom, M. E., Peltola, P., Ronnback, P., Lavergren, U., Bergback, B., Tarvainen, T., Backman, B., and Salminen, R.: Uranium in surface and groundwaters in Boreal Europe, Geochemistry: Exploration, Environment, Analysis, 9, 51-62, doi:10.1144/14677873/08-185, 2009.

Bishop, K., Buffam, I., Erlandsson, M., Folster, J., Laudon, H., Seibert, J. and Temnerud, J.: Aqua Incognita: the unknown headwaters, Hydrol. Process., 22, 1239-1242, doi:10.1002/hyp.7049, 2008.

Björkvald, L., Buffam, I., Laudon, H., and Mörth, C.-M.: Hydrogeochemistry of $\mathrm{Fe}$ and $\mathrm{Mn}$ in small boreal streams: The role of seasonality, landscape type and scale, Geochim. Cosmochim. Acta, 72, 2789-2804, doi:10.1016/j.gca.2008.03.024, 2008.

Buffam, I., Laudon, H., Seibert, J., Mörth, C.-M., and Bishop, K.: Spatial heterogeneity of the spring flood acid pulse in a boreal stream network, Sci. Total Environ., 407, 708-722, doi:10.1016/j.scitotenv.2008.10.006, 2008.

Cory, N., Buffam, I., Laudon, H., Kohler, S., and Bishop, K.: Landscape control of stream water aluminum in a boreal catchment during spring flood, Environ. Sci. Technol., 40, 3494-3500, doi:10.1021/es0523183, 2006.

Cory, N., Buffam, I., Laudon, H., Bjorkvald, L., Morth, C., Kohler, S., and Bishop, K.: Particulate aluminium in boreal streams: Towards a better understanding of its sources and influence on dissolved aluminium speciation, Appl. Geochem., 24, 1677-1685, doi:10.1016/j.apgeochem.2009.04.038, 2009.

Dunk, R. M., Mills, R. A., and Jenkins, W. J.: A reevaluation of the oceanic uranium budget for the Holocene, Chem. Geol., 190, 45-67, doi:10.1016/S0009-2541(02)00110-9, 2002.

Engstrom, E., Rodushkin, I., Ingri, J., Baxter, D. C., Ecke, F., Osterlund, H., and Ohlander, B.: Temporal isotopic variations of dissolved silicon in a pristine boreal river, Chem. Geol., 271, 142152, doi:10.1016/j.chemgeo.2010.01.005, 2010.

Frengstad, B., Midtgård Skrede, A. K., Banks, D., Reidar Krog, J., and Siewers, U.: The chemistry of Norwegian groundwaters: III. The distribution of trace elements in 476 crystalline bedrock groundwaters, as analysed by ICP-MS techniques, The Science of The Total Environment, 246, 21-40, doi:10.1016/S00489697(99)00413-1, 2000.

Gorham, E.: Northern Peatlands: Role in the Carbon Cycle and Probable Responses to Climatic Warming, Ecol. Appli., 1, 182195, 1991.

Gustafsson, J. P.: Visual MINTEQ 3.0, http://www2.lwr.kth.se/ english/OurSoftware/Vminteq/index.html, 2012.

Hu, Q., Weng, J., and Wang, J.: Sources of anthropogenic radionuclides in the environment: a review, J. Environ. Radioact., 101, 426-437, doi:10.1016/j.jenvrad.2008.08.004, 2010.

Kalin, M., Wheeler, W. N., and Meinrath, G.: The removal of uranium from mining waste water using 
algal/microbial biomass, J. Environ. Radioact., 78, 151-177, doi:10.1016/j.jenvrad.2004.05.042, 2005.

Kerr, S., Shafer, M., Overdier, J., and Armstrong, D.: Hydrologic and biogeochemical controls on trace element export from northern Wisconsin wetlands, Biogeochemistry, 89, 273-294, doi:10.1007/s10533-008-9219-2, 2008.

Klaminder, J., Bindler, R., Laudon, H., Bishop, K., Emteryd, O., and Renberg, I.: Flux rates of atmospheric lead pollution within soils of a small catchment in northern Sweden and their implications for future stream water quality, Environ. Sci. Technol., 40, 46394645, doi:10.1021/es0520666, 2006.

Köhler, S., Buffam, I., Seibert, J., Bishop, K., and Laudon, H.: Dynamics of stream water TOC concentrations in a boreal headwater catchment: Controlling factors and implications for climate scenarios, J. Hydrol., 373, 44-56, doi:10.1016/j.jhydrol.2009.04.012, 2009a.

Köhler, S., Lidman, F., Hassellov, M., Stolpe, B., Morth, M., Bjorkvald, L., and Laudon, H.: Temporal variations in the export of REE in boreal catchments of varying character and size, Geochim. Cosmochim. Acta, 73, A674-A674, 2009 b.

Krachler, M. and Shotyk, W.: Natural and anthropogenic enrichments of molybdenum, thorium, and uranium in a complete peat bog profile, Jura Mountains, Switzerland, J. Environ. Monitor., 6, 418-426, doi:10.1039/b313300a, 2004.

Kröpfelová, L., Vymazal, J., Svehla, J., and Stíchová, J.: Removal of trace elements in three horizontal sub-surface flow constructed wetlands in the Czech Republic, Environ. Pollut., 157, 11861194, doi:10.1016/j.envpol.2008.12.003, 2009.

Kumar, A., Mishra, P., Ghosh, S., Sharma, P., Ali, M., Pandey, B., and Mishra, K.: Thorium-induced oxidative stress mediated toxicity in mice and its abrogation by Diethylenetriamine pentaacetate, Int. J. Radiat. Biol., 84, 337-349, doi:10.1080/09553000801983133, 2008.

Langmuir, D. and Herman, J. S.: The mobility of thorium in natural waters at low temperatures, Geochim. Cosmochim. Acta, 44, 1753-1766, doi:10.1016/0016-7037(80)90226-4, 1980.

Laudon, H., Seibert, J., Kohler, S., and Bishop, K.: Hydrological flow paths during snowmelt: Congruence between hydrometric measurements and oxygen 18 in meltwater, soil water, and runoff, Water Resour. Res., 40, doi:10.1029/2003WR002455, 2004

Laudon, H., Sjoblom, V., Buffam, I., Seibert, J., and Morth, M.: The role of catchment scale and landscape characteristics for runoff generation of boreal streams, J. Hydrol., 344, 198-209, 2007.

Lidman, F., Morth, C., Bjorkvald, L., and Laudon, H.: Selenium Dynamics in Boreal Streams: The Role of Wetlands and Changing Groundwater Tables, Environ. Sci. Technol., 45, 2677-2683, doi:10.1021/es102885z, 2011.

Lidman, F., Ramebäck, H., Bengtsson, Å., and Laudon, H.: Distribution and transport of radionuclides in a boreal mire - assessingn past, present and future accumulation of uranium, thorium and radium, J. Environ. Radioactiv., in press, doi:10.1016/j.jenvrad.2012.06.010, 2012.

Nilsson, M., Mikkelä, C., Sundh, I., Granberg, G., Svensson, B. H., and Ranneby, B.: Methane emission from Swedish mires: National and regional budgets and dependence on mire vegetation, J. Geophys. Res., 106, 20847-20860, doi:200110.1029/2001JD900119, 2001.
Olivie-Lauquet, G., Gruau, G., Dia, A., Riou, C., Jaffrezic, A., and Henin, O.: Release of Trace Elements in Wetlands: Role of Seasonal Variability, Water Res., 35, 943-952, doi:10.1016/S00431354(00)00328-6, 2001.

Owen, D. E. and Otton, J. K.: Mountain wetlands: Efficient uranium filters - potential impacts, Ecol. Eng., 5, 77-93, doi:10.1016/0925-8574(95)00013-9, 1995.

Porcelli, D., Andersson, P., Wasserburg, G., Ingri, J., and Baskaran, M.: The importance of colloids and mires for the transport of uranium isotopes through the Kalix River watershed and Baltic Sea, Geochim. Cosmochim. Acta, 61, 4095-4113, 1997.

Prat, O., Vercouter, T., Ansoborlo, E., Fichet, P., Perret, P., Kurttio, P., and Salonen, L.: Uranium Speciation in Drinking Water from Drilled Wells in Southern Finland and Its Potential Links to Health Effects, Environ. Sci. Technol., 43, 3941-3946, doi:10.1021/es803658e, 2009.

Rodushkin, I., Nordlund, P., Engstrom, E., and Baxter, D. C.: Improved multi-elemental analyses by inductively coupled plasma-sector field mass spectrometry through methane addition to the plasma, J. Anal. At. Spectrom., 20, 1250-1255, doi:10.1039/b507886e, 2005.

Saari, H., Schmidt, S., Huguet, S., and Lanoux, A.: Spatiotemporal variation of dissolved U-238 in the Gironde fluvialestuarine system (France), J. Environ. Radioacti., 99, 426-435, doi:10.1016/j.jenvrad.2007.11.016, 2008.

Schöner, A., Noubactep, C., Büchel, G., and Sauter, M.: Geochemistry of natural wetlands in former uranium milling sites (eastern Germany) and implications for uranium retention, Chemie der Erde - Geochemistry, 69(Supplement 2), 91-107, doi:10.1016/j.chemer.2007.12.003, 2009.

Seibert, J., Grabs, T., Köhler, S., Laudon, H., Winterdahl, M., and Bishop, K.: Linking soil- and stream-water chemistry based on a Riparian Flow-Concentration Integration Model, Hydrol. Earth Syst. Sci., 13, 2287-2297, doi:10.5194/hess-13-22872009, 2009.

Sheoran, A. S. and Sheoran, V.: Heavy metal removal mechanism of acid mine drainage in wetlands: A critical review, Minerals Eng., 19, 105-116, doi:10.1016/j.mineng.2005.08.006, 2006.

Shotyk, W.: Review of the inorganic geochemistry of peats and peatland waters, Earth-Sci. Rev., 25, 95-176, 1988.

Sirin, A., Kohler, S. and Bishop, K.: Resolving flow pathways and geochemistry in a headwater forested wetland with multiple tracers, Hydrology, Water Resour. Ecol. Headwaters, 337-342, 1998.

Temnerud, J. and Bishop, K.: Spatial variation of streamwater chemistry in two Swedish boreal catchments: Implications for environmental assessment, Environ. Sci. Technol., 39, 14631469, 2005.

Thunblom, B., Lindén, A. H., and Gustafsson, B.: Concentrations of Uranium, Thorium and Potassium in Sweden, SSI Rapport 2005:04, 2005.

Viscarra Rossel, R. A., McBratney, A. B., and Minasny, B.: Proximal Soil Sensing, Springer Netherlands, Dordrecht, 2010.

Wedepohl, H. K.: The composition of the continental crust, Geochimica et Cosmochim. Acta, 59, 1217-1232, doi:10.1016/0016-7037(95)00038-2, 1995.

Yeghicheyan, D., Carignan, J., Valladon, M., Le Coz, M. B., Le Cornec, F., Castrec-Rouelle, M., Robert, M., Aquilina, L., Aubry, E., Churlaud, C., Dia, A., Deberdt, S, Dupr, B., Freydier, R., Gruau, G., Henin, O., de Kersabiec, A. M., Mace, J, Marin, L., 
Morin, N., Petitjean, P., and Serrat, E.: A compilation of silicon and thirty one trace elements measured in the natural river water reference material SLRS-4 (NRC-CNRC), Geostand. Newsl., 25, 465-474, doi:10.1111/j.1751-908X.2001.tb00617.x, 2001.

Zaccone, C., Cocozza, C., Cheburkin, A. K., Shotyk, W., and Miano, T. M.: Enrichment and depletion of major and trace elements, and radionuclides in ombrotrophic raw peat and corresponding humic acids, Geoderma, 141, 235-246, doi:10.1016/j.geoderma.2007.06.007, 2007.
Zoriy, P., Ostapczuk, P., Dederichs, H., Hobig, J., Lennartz, R., and Zoriy, M.: Biomonitoring of environmental pollution by thorium and uranium in selected regions of the Republic of Kazakhstan, J. Environ. Radioactiv., 101, 414-420, doi:10.1016/j.jenvrad.2010.02.014, 2010. 